\title{
PUDING TALAS, CEMILAN DARI KOTA BOGOR
}

\author{
[Taro Pudding, Snack From Bogor City] \\ Julia Ratnawulan Skawanti ${ }^{1)}$, Yuviani Kusumawardhani ${ }^{2)}$ \\ 1)Sekolah Tinggi Pariwisata Bogor, Jl. Curug mekar no 17, Yasmin, Bogor \\ 2)Sekolah Tinggi Pariwisata Bogor, Jl. Curug mekar no 17, Yasmin, Bogor
}

Diterima 15 Oktober 2020 / Disetujui 27 November 2020

\begin{abstract}
Traditional food can be used as a culinary tour that can raise the image and income of the community from the area. Bogor is one of the regions in Indonesia which is famous for producing taro plants. Taro can be used as a substitute for rice, especially at a critical time of rice availability in Indonesia because taro contains a lot of carbohydrates. Taro can be processed into various traditional foods such as steamed taro, taro layer, taro chips, taro pudding, taro rolls cake and so on. Taro pudding is one of the most sought-after foods for consumers because of its soft texture and much preferred taste. On Saturdays and Sundays even during long weekends, the city of Bogor is flooded with visitors from outside the region for culinary tours.
\end{abstract}

Keywords: Bogor, Taro, Pudding, Traditional Food

\begin{abstract}
ABSTRAK
Makanan tradisional dapat dijadikan sebagai suatu wisata kuliner yang dapat mengangkat citra dan pendapatan masyarakat dari daerah tersebut. Bogor adalah salah satu daerah di Indonesia yang terkenal dengan pengahasil tanaman talas. Talas bisa dijadikan sebagai pengganti nasi terutama pada saat kritis ketersediaan beras di Indonesia karena talas banyak mengandung karbohidrat. Talas dapat diolah menjadi berbagai makanan tradisional seperti talas kukus,lapis talas, keripik talas, puding talas, bolu gulung talas dan sebagainya. Puding talas salah satu makanan yang banyak dicari konsumen karena teksturnya lembut dan rasanya yang banyak disuka. Pada hari Sabtu dan Minggu bahkan pada saat long weekend, kota Bogor kebanjiran pengunjung dari luar daerah untuk berwisata kuliner.
\end{abstract}

Kata Kunci: Bogor, Talas, Puding, Makanan Tradisional.

\section{PENDAHULUAN}

Makanan adalah produk pangan yang siap hidang atau yang langsung dapat dimakan. Makanan biasanya dihasilkan dari bahan pangan setelah terlebih dahulu diolah atau dimasak (Soekarto, 1990). Sedangkan yang termasuk makanan tradisional adalah makanan dan minuman serta bahan-bahan campuran yang secara tradisional telah digunakan dan berkembang di daerah atau masyarakat Indonesia (Anonim, 1996).

*Korespondensi Penulis:

E-mail: juliaratnawulan@gmail.com ${ }^{(1)}$ kusumawadhaniyuvi@gmail.com $^{(2)}$
Menjaga kelestarian makanan tradisional di tengah gempuran makanan asing sangat penting untuk dilakukan. Tidak hanya menjadi bagian yang tak terpisahkan dari budaya, menjaga eksistensi kuliner tradisional serta menempatkannya sejajar atau bahkan lebih tinggi dari kuliner asing, akan memberi dampak yang luas bagi masyarakat. Salah satu cara yang bisa dilakukan adalah dengan mengonsumsi makanan tradisional.

Makanan tradisional setiap daerah berbeda sesuai dengan keadaan tempat dan budaya, tetapi biasanya berasal dari tanaman baik dari serealia seperti beras, gandung, jagung maupun umbi-umbian seperti kentang, ubi jalar, talas, ganyong dan singkong. Nama ilmiah talas adalah Colocasia esculenta dan terdapat beberapa varietas talas di Indonesia 
seperti talas mentega, talas hijau, talas Bogor, talas beneng dari Banten, talas semir dari Sumedang, talas seler dari Ciamis dan talas Kalbar.

Sejak dahulu talas menjadi primadona sebagai oleh-oleh bagi wisatawan yang berkunjung ke kota ini. Biasanya dijual seikat dengan harga berkisar $\mathrm{Rp} 25.000$ sampai dengan $\mathrm{Rp} 50.000$, namun saat ini banyak olahan yang terbuat dari bahan dasar talas. Potensi inilah yang dikembangkan oleh pemerintahan kota Bogor sebagai tujuan wisata kuliner terutama bagi wisatawan atau warga diluar Bogor.

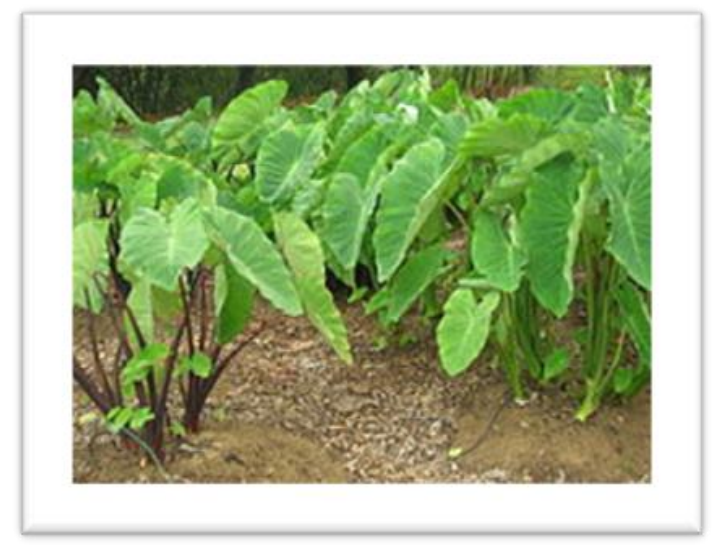

Gambar 1.

Pohon Talas

Pada saat ini banyak toko kue yang berlomba-lomba memproduksi lapis talas dengan berbagai bentuk dan variasi. Talas tidak hanya dapat dibuat sebagai lapis talas saja tetapi dapat dibuat menjadi puding talas. Permasalahannya yaitu mampukah pudding talas menyaingi ketenaran lapis talas sebagai primadona oleh-oleh khas dari kota Bogor? Mampukah puding talas meningkatkan pertumbuhan ekonomi masyarakat kota Bogor?

Penelitian yang mencakup aspek survei puding talas dan dilanjutkan dengan penelitian deskriptif singkat yang sangat diperlukan sebagai data dasar untuk menunjang langkah berikutnya. Hasil penelitian ini akan sangat berguna sebagai bahan penelitian makanan tradisional khas Bogor terutama sekali dalam mengembangkan peran serta LPPM Sekolah Tinggi Pariwisata Bogor.

\section{METODE PENELITIAN}

Materi penelitian adalah produk makanan olahan dari bahan dasar talas terutama puding talas yang dijual di Klapertaart Huize Bogor. Data yang diperlukan dalam survei meliputi rasa, tampilan dan tekstur puding.

Dalam pelaksanaan survei tersebut peneliti mengadakan pengamatan pada produk yang dihasilkan oleh bahan dasar talas, kemudian dilakukan tanya jawab dengan pembuat tentang hal-hal yang berkaitan dengan produk, bahan utama dan bahan lain yang digunakan.

\section{HASIL DAN PEMBAHASAN}

\section{Kandungan Nutrisi Talas}

Umbi talas segar mengandung $63-85 \%$ air dengan $13-29 \%$ karbohidrat. Pati merupakan komponen karbohidrat utama di dalam umbi talas. Selain itu, umbi talas juga mengandung protein, sedikit lemak dan kaya kalsium, fosfor, besi, vitamin C, tiamin, riboflavin dan niasin Meskipun bukan zat gizi, kandungan serat di dalam talas juga cukup tinggi. Kehadiran serat sangat baik untuk menjaga kesehatan saluran pencernaan.

Tabel 1. Komposisi Kimia Talas Segar

\begin{tabular}{|l|l|}
\hline Komponen & Komposisi \\
\hline Kadar air & $63-85 \%$ \\
\hline Karbohidrat (sebagian besar dalam bentuk pati) & $13-29 \%$ \\
\hline Protein & $1.4-3.0 \%$ \\
\hline Lemak & $0.16-0.36 \%$ \\
\hline Serat kasar & $0.60-1.18 \%$ \\
\hline Abu & $0.60-1.3 \%$ \\
\hline Vitamin C & $7-9 \mathrm{mg} / 100 \mathrm{~g}$ \\
\hline Tiamin & $0.18 \mathrm{mg} / 100 \mathrm{~g}$ \\
\hline Riboflavin & $0.04 \mathrm{mg} / 100 \mathrm{~g}$ \\
\hline Niasin & $0.9 \mathrm{mg} / 100 \mathrm{~g}$ \\
\hline
\end{tabular}

Sumber: ilmupangan.blogspot.co.id

Dengan kadar air yang tinggi, maka seperti bahan pangan segar lainnya, umbi talas segar mudah rusak selama penyimpanan. Untuk mempermudah penggunaan dan memperpanjang umur simpannya, umbi talas diolah menjadi tepung talas atau diekstrak patinya sehingga diperoleh pati talas. 
Dalam bentuk tepung, talas memiliki komposisi nutrisi yang lebih baik dibandingkan beras. Dari Tabel 2 terlihat bahwa kadar air yang relatif sama, tepung talas mengandung protein yang lebih tinggi dan dengan kadar lemak yang lebih rendah daripada beras. Kandungan serat talas juga cukup tinggi. Kehadiran serat ini sangat baik untuk menjaga kesehatan saluran cerna. Granula dari pati talas berukuran kecil sehingga mudah dicerna dan dapat digunakan sebagai ingredien untuk makanan pengganti ASI (MP-ASI). Talas memiliki banyak getah (gum). Keberadaan gum ini, dan kadar amilopektinnya yang lebih tinggi dari amilosa menyebabkan rasa dan tekstur talas menjadi lengket dan pulen.

Tabel 2. Perbandingan komposisi kimia tepung talas dengan beras

\begin{tabular}{|l|r|r|}
\hline Komponen & Talas & Beras \\
\hline Kadar air $(\mathrm{g} / 100 \mathrm{~g})$ & 10.20 & 9.06 \\
\hline Protein $(\mathrm{g} / 100 \mathrm{~g})$ & 12.25 & 10.50 \\
\hline Lemak $(\mathrm{g} / 100 \mathrm{~g})$ & 0.50 & 1.01 \\
\hline Abu $(\mathrm{g} / 100 \mathrm{~g})$ & 4.15 & 0.78 \\
\hline Serat kasar $(\mathrm{g} / 100 \mathrm{~g})$ & 0.75 & 0.20 \\
\hline Karbohidrat total $(\mathrm{g} / 100 \mathrm{~g})$ & 72.15 & 78.45 \\
\hline Pati $(\mathrm{g} / 100 \mathrm{~g})$ & 67.42 & 67.42 \\
$\bullet$ Amilosa $(\mathrm{g} / 100 \mathrm{~g})$ & 2.25 & 9.32 \\
• Amilopektin $(\mathrm{g} / 100 \mathrm{~g})$ & 65.17 & 58.10 \\
\hline
\end{tabular}

Sumber : ilmupangan.blogspot.co.id

\section{Masalah Dalam Konsumsi Talas Dan Cara Mengatasinya}

Masalah terbesar dalam pemanfaatan talas sebagai bahan pangan adalah timbulnya rasa gatal, sensasi terbakar dan iritasi pada kulit, mulut, tenggorokan dan saluran cerna pada saat dikonsumsi. Hal ini disebabkan oleh kalsium oksalat dan asam oksalat yang ada di dalam talas. Keberadaan asam oksalat diduga dapat mengganggu penyerapan kalsium. Asam oksalat bersifat larut dalam air, sementara kalsium oksalat tidak larut dalam air tetapi larut dalam asam kuat. Oksalat tidak tersebar secara merata di dalam umbi talas. Bagian pangkal umbi biasanya memiliki kadar oksalat lebih tinggi daripada bagian ujung. Kadar oksalat juga bervariasi antar varietas. Dua cara yang dapat dilakukan untuk mengubah kalsium oksalat menjadi bentuk yang larut air adalah dengan perendaman irisan talas dalam larutan asam kuat (asam klorida, $\mathrm{HCl} 0,3 \mathrm{M}$ ) selama 5 menit atau perendaman didalam larutan garam $\mathrm{NaCl} 7.5 \%$ selama 1 jam.

\section{Pemanfaatan Tepung Talas}

Tepung talas berpotensi untuk digunakan sebagai ingredien untuk pembuatan produk baru ataupun untuk mengganti tepung-tepung konvensional. Tepung, talas memiliki kapasitas absorpsi air yang tinggi sehingga dapat digunakan sebagai pengental untuk soup ataupun produk olahan lainnya. Tepung talas juga memiliki kapasitas absorpsi lemak yang tinggi. Dengan kapasitas absorpsi airnya yang juga tinggi, maka tepung ini sangat potensial digunakan untuk mempertahankan flavor, memperbaiki palatabilitas dan memperpanjang umur simpan produk olahan daging, maupun produk-produk lainnya seperti whipped toppings, sosis, chiffon, deserts, angel cake dan sponge cake. Pasta tepung talas tidak mengalami peningkatan kekentalan selama proses pendinginan. Karakter ini memungkinkan aplikasi tepung talas pada produk-produk yang mensyaratkan stabilitas pasta selama penyimpanan produk di suhu dingin.

\section{Bahan dan Cara Membuat}

Bahan dasar pembuatan puding adalah talas bogor. Setelah talas dibersihkan dan direndam selama satu jam dalam larutan garam untuk menghilangkan kadar oksalatnya. Kemudian kukus selama tiga puluh menit hingga talas dapat dihaluskan. Karena talas mengandung amilopektin yang tinggi sehingga talas tidak mudah untuk dihaluskan, oleh sebab itu diperlukan bahan lain seperti tepung singkong untuk mengimbangan tekstur tersebut. Selain bahan dasar talas juga dibutuhkan tepung agar-agar, tepung singkong, susu cair, gula pasir, kenari, kelapa muda, pewarna makanan dan garam.

Satukan talas dan tepung singkong, tepung agar-agar dan susu cair ke dalam paci, kemudian masak dengan menggunakan api kecil sambil diaduk terus supaya susu tidak pecah. Tambahkan garam, gula pasir dan pewarna makanan. Setelah mengental tuang kedalam cetakan dan beri irisan kenari serta kelapa muda. Masukan puding ke dalam lemari pendingin dan biarkan selama 
beberapa jam hingga agak mengeras dan siap dinikmati.

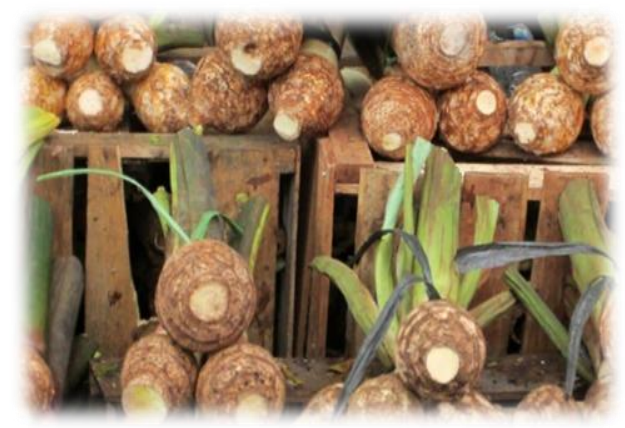

Gambar 2.

Talas Bogor

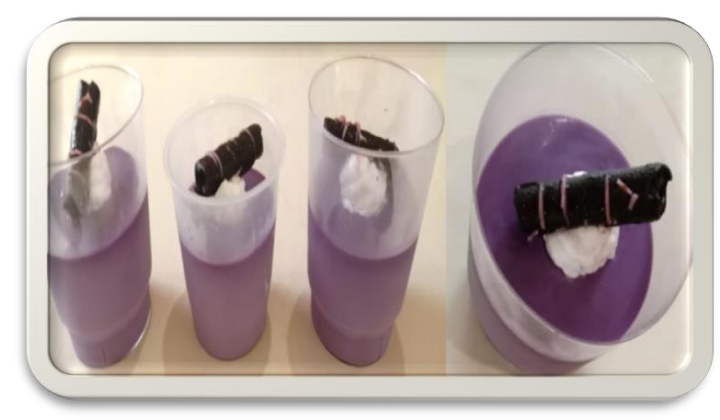

Gambar 3.

Puding Talas
Puding talas dalam penelitian ini sudah dapat dinikmati di Klapertart Huize and Resto (Triple Combo) Bogor yang berlokasi di Jl. Pangrango no 25 kota Bogor.

\section{DAFTAR PUSTAKA}

Anonim. (1996). Panduan Pusat Kajian Makanan Tradisional. Kantor MenPangan - Depdikbud. Jakarta.

Rosyidi, D. (2006). Macam-Macam Makanan Tradisional Yang Terbuat Dari Hasil Ternak Yang Beredar Di Kota Malang. Jurnal Ilmu dan Teknologi Hasil Ternak Vol.I No.1, Agustus 2006

Soekarto, S.T. (1990). Dasar-dasar Pengawasan dan Standarisasi Mutu Pangan. PAU - Pangan dan Gizi. IPB. Bogor

http://ilmupangan.blogspot.co.id/2012/06/tala s-andalan-bogor 427.html (25 Juli 2020)

www.sahabatnestle.co.id/content/view/umbitalas-sumber-karbohidrat-murahpengganti-nasi.html (25 Juli 2020)

https://id.wikipedia.org/wiki/Talas (25 Juli 2020)

\section{SIMPULAN}

Talas merupakan salah satu makanan khas Kota Bogor. Talas Bogor terkenal kelezatannya dan ukurannya yang cukup besar. Namun, seringkali pengolahan talas yang tidak benar memunculkan rasa gatal, sensasi terbakar dan iritasi pada kulit, mulut, tenggorokan dan saluran cerna pada saat dikonsumsi. Oleh karenanya, perlakuan pada talas sebelum diolah menjadi suatu makanan harus dilakukan dengan benar. Puding talas dalam penelitian ini menggunakan talas sebagai bahan dasarnya. Talas dicampur dengan bahan lainnya seperti tepung agaragar, tepung singkong, susu cair, gula pasir, kenari, kelapa muda, pewarna makanan dan garam untuk menjadi sebuah puding yang bercita rasakan talas. Puding talas ini dapat menjadi inovasi bagi makanan khas Bogor, sehingga para wisatawan yang berkunjung ke Bogor dapat menikmati talas dalam bentuk puding yang manis dan enak. 